\title{
Derivatives of 2-iodoxybenzenesulfonic acid: new pseudocyclic hypervalent iodine reagents
}

\author{
Viktor V. Zhdankin,* Rostyslav N. Goncharenko, Dmitry N. Litvinov, \\ and Alexey Y. Koposov \\ Department of Chemistry, University of Minnesota Duluth, Duluth, Minnesota 55812, USA \\ E-mail: vzhdanki@d.umn.edu
}

Dedicated to Professor Nikolai Zefirov on his $70^{\text {th }}$ birthday

(received 11 July 04; accepted 03 Sep 04; published on the web 14 Sep 04)

\begin{abstract}
Amides and esters of 2-iodoxybenzenesulfonic acid were prepared by dimethyldioxirane oxidation of the respective monovalent iodine derivatives and isolated as stable, microcrystalline compounds. These new hypervalent iodine reagents with a pseudobenziodoxole structure are efficient oxidizers of alcohols, secondary amines and sulfides.
\end{abstract}

Keywords: Hypervalent iodine, oxidation, pseudobenziodoxole, IBX

\section{Introduction}

In the past decade the hypervalent heterocyclic iodine reagents have emerged as reagents of choice for various synthetically useful transformations. ${ }^{1}$ In particular, the heterocyclic $\lambda^{5}$-iodane 1-hydroxy-1,2-benziodoxol-3(1H)-one 1-oxide (IBX, 1), has received a widespread application in organic synthesis as a highly efficient and mild oxidant that can be used for a selective oxidation of primary and secondary alcohols, selective oxidations of secondary amines and for a variety of other important oxidations. ${ }^{1,2}$ However, despite its useful oxidizing properties, practical application of IBX is restricted due to the potentially explosive nature and the extremely low solubility of this reagent. Several research groups have tried to improve IBX by structurally modifying it, ${ }^{3,4}$ or by developing polymer supported analogs. ${ }^{5}$ Recently, we reported the synthesis of IBX-amides (2) ${ }^{4 \mathrm{a}}$ and IBX-esters (3), ${ }^{4 \mathrm{~b}}$ which are stable and soluble reagents having oxidizing properties similar to IBX. 
<smiles>O=C1OI(=O)(O)c2ccccc21</smiles>

1<smiles></smiles>

2<smiles></smiles>

3

Figure 1

According to X-ray data, these new reagents (2 and 3) have the pseudobenziodoxole structure due to the intramolecular secondary bonding between iodine and carboxylic oxygen. In comparison with IBX and other benziodoxoles, pseudobenziodoxoles have much better solubility, which is explained by a partial disruption of their polymeric nature due to the redirection of $\mathrm{I} \bullet \cdot \mathrm{O}$ secondary bonding. ${ }^{4}$ Very recently, Lee and co-workers reported the preparation of the polymer supported IBX-esters and IBX-amides, which showed excellent oxidative activity toward benzylic alcohols. ${ }^{6}$

We now report the preparation and reactivity of amides $^{7}$ and esters of 2iodoxybenzenesulfonic acid, which represent a new class of pseudocyclic hypervalent iodine reagents. These novel pseudobenziodoxoles are efficient oxidizers of alcohols, secondary amines and sulfides.

\section{Results and Discussion}

The starting materials for the preparation of 2-iodoxybenzenesulfonamides 5, were obtained from 2-iodobenzenesulfonyl chloride $\mathbf{4}$ and the appropriate amino compounds, ${ }^{8}$ such as esters of natural amino acids (5a-d) or (R)-1-phenylethylamine (5e) (Scheme 1).<smiles>O=S(=O)(Cl)c1ccccc1I</smiles>

4

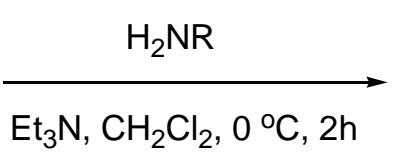

a: $\mathrm{R}=(\mathrm{S})-\mathrm{CH}\left(\mathrm{CH}_{3}\right) \mathrm{CO}_{2} \mathrm{CH}_{3}$

b: $\mathrm{R}=(\mathrm{S})-\mathrm{CH}\left(\mathrm{CH}_{2} \mathrm{Ph}\right) \mathrm{CO}_{2} \mathrm{CH}_{3}$

c: $\mathrm{R}=(\mathrm{S})-\mathrm{CH}(\mathrm{i}-\mathrm{Pr}) \mathrm{CO}_{2} \mathrm{CH}_{3}$

d: $\mathrm{R}=(\mathrm{S})-\mathrm{CH}(\mathrm{i}-\mathrm{Bu}) \mathrm{CO}_{2} \mathrm{CH}_{3}$

e: $\mathrm{R}=(\mathrm{R})-\mathrm{CH}(\mathrm{Ph}) \mathrm{CH}_{3}$

\section{Scheme 1}<smiles>[R]NS(=O)(=O)c1ccccc1I</smiles>

5a-e (43-71\%)

The starting esters of 2-iodobenzenesulfonic acid $\mathbf{6}$ were prepared by a known method from the corresponding alcohols and 2-iodobenzenesulfonyl chloride ${ }^{9}$ (Scheme 2). 
<smiles>O=S(=O)(Cl)c1ccccc1I</smiles>

4

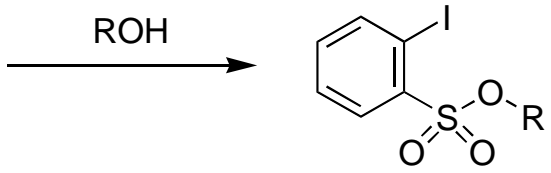

6a,b (65-68\%)

a: $\mathrm{R}=\mathrm{CH}_{3}$

b: $\mathrm{R}=\mathrm{C}_{2} \mathrm{H}_{5}$

\section{Scheme 2}

The dimethyldioxirane oxidation of iodoarenes $\mathbf{5}$ and $\mathbf{6}$ afforded the respective iodylarenes (7 and 8) in good yields (Scheme 3). All products were isolated by filtration of the reaction mixture in the form of stable, white, microcrystalline solids. In the case of esters of 2iodobenzenesulfonic acid 5 the procedure of oxidation was slightly modified: dimethyldioxirane was used in methylene chloride solution instead of acetone.<smiles>[R]S(=O)(=O)c1ccccc1I</smiles>

5 or 6

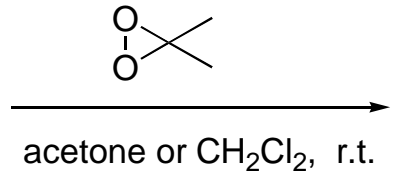

$$
\begin{aligned}
& \text { 7a: } \mathrm{R}=(\mathrm{S})-\mathrm{NHCH}\left(\mathrm{CH}_{3}\right) \mathrm{CO}_{2} \mathrm{CH}_{3} \\
& \text { 7b: } \mathrm{R}=(\mathrm{S})-\mathrm{NHCH}\left(\mathrm{CH}_{2} \mathrm{Ph}\right) \mathrm{CO}_{2} \mathrm{CH}_{3} \\
& \text { 7c: } \mathrm{R}=(\mathrm{S})-\mathrm{NHCH}(\mathrm{i}-\mathrm{Pr}) \mathrm{CO}_{2} \mathrm{CH}_{3} \\
& \text { 7d: } \mathrm{R}=(\mathrm{S})-\mathrm{NHCH}(\mathrm{i}-\mathrm{Bu}) \mathrm{CO}_{2} \mathrm{CH}_{3} \\
& \text { 7e: } \mathrm{R}=(\mathrm{R})-\mathrm{NHCH}(\mathrm{Ph}) \mathrm{CH}_{3}
\end{aligned}
$$<smiles></smiles>

7 or 8

\section{Scheme 3}

8a: $\mathrm{R}=\mathrm{OCH}_{3}$

8b: $\mathrm{R}=\mathrm{OC}_{2} \mathrm{H}_{5}$

Products $\mathbf{7}$ and $\mathbf{8}$ were identified on the basis of spectroscopic data and elemental analysis. In particular, IR spectra of all compounds showed a sulfonyl absorption at $1330-1340 \mathrm{~cm}^{-1}$, the I=O absorption at $740-780 \mathrm{~cm}^{-1}$, as well as the carbonyl stretch at $1720-1740 \mathrm{~cm}^{-1}$ for the amino acid derivatives 7a-d. In ${ }^{1} \mathrm{H}$ NMR spectra, the signals corresponding to the aromatic ring and the fragment $\mathrm{R}$ of the molecule were observed. In addition, the $\mathrm{N}-\mathrm{H}$ protons in 2iodoxybenzenesulfonamides 7 were observed as characteristic doublets at $8.40-8.60 \mathrm{ppm}$. In ${ }^{13} \mathrm{C}$ NMR of iodoxyarenes 7 and $\mathbf{8}$, the most characteristic was the signal of $\mathrm{C}-\mathrm{IO}_{2}$ at $146 \mathrm{ppm}$. The ESI-HRMS spectra of compounds $\mathbf{7}$ and $\mathbf{8}$ demonstrated strong $[\mathrm{M}+\mathrm{Na}]^{+}$peaks as well as weaker peaks corresponding to the dimers $[2 \mathrm{M}+\mathrm{Na}]^{+}$and the trimers $[3 \mathrm{M}+\mathrm{Na}]^{+}$.

Based on our previous X-ray studies ${ }^{4}$ and on the literature data ${ }^{10}$ we assume that compounds $\mathbf{7}$ and $\mathbf{8}$ have planar pseudocyclic structure with strong intramolecular interaction between hypervalent iodine center and the oxygen atom in the ortho-substituent. Several X-ray molecular structures of pseudobenziodoxoles were reported in the literature, ${ }^{4,10}$ including the 2-sulfonyl substituted iodylarene. ${ }^{10 a}$ However, in contrast to the previously reported pseudobenziodoxoles 2 
and $3,{ }^{4}$ compounds $\mathbf{7}$ and $\mathbf{8}$ have a relatively low solubility in non-polar organic solvents such as chloroform and methylene chloride. Moreover, the presence of $2 \mathrm{M}^{+}$and $3 \mathrm{M}^{+}$peaks in the ESIMS data indicates the oligomeric or polymeric structure of these compounds. A similar oligomeric assembly directed by a relatively weak intermolecular $\mathrm{I} \bullet \bullet \mathrm{O}$ secondary bonding was previously reported for IBX-amides 2 and IBX-esters 3 . $^{4}$

Preliminary experiments demonstrate that 2-iodoxybenzenesulfonamides 7 show aspects of reactivity similar to previously reported IBX-amides 2 . In particular, reagents 7a-e can cleanly oxidize benzyl alcohol to benzaldehyde in chloroform at $50{ }^{\circ} \mathrm{C}$ (Table 1). Reagent 7e shows the highest reactivity in this reaction and 7a the lowest reactivity, which is probably explained by the lowest solubility of $7 \mathbf{a}$ in chloroform.

Table 1. Oxidation of benzyl alcohol with reagents $7^{\mathrm{a}, \mathrm{b}}$

\begin{tabular}{|c|c|c|c|c|}
\hline Entry & Reagent $7^{\mathrm{c}}$ & Solvent & Reaction time (h) & Conversion $(\%)^{\mathrm{d}}$ \\
\hline 1 & $7 \mathbf{a}$ & $\mathrm{CDCl}_{3}$ & 22 & 20 \\
\hline 2 & $7 a$ & DMSO- $d_{6}$ & 22 & 8 \\
\hline 3 & $7 \mathbf{b}$ & $\mathrm{CDCl}_{3}$ & 22 & 77 \\
\hline 4 & $7 \mathbf{b}$ & $\mathrm{DMSO}_{-} \mathrm{d}_{6}$ & 22 & 11 \\
\hline 5 & 7c & $\mathrm{CDCl}_{3}$ & 22 & 43 \\
\hline 6 & 7c & DMSO- $\mathrm{d}_{6}$ & 22 & 1 \\
\hline 7 & 7d & $\mathrm{CDCl}_{3}$ & 22 & 65 \\
\hline 8 & 7d & $\mathrm{DMSO}_{-} \mathrm{d}_{6}$ & 22 & 9 \\
\hline 9 & $7 e$ & $\mathrm{CDCl}_{3}$ & 17 & 100 \\
\hline 10 & $7 e$ & $\mathrm{DMSO}_{-} \mathrm{d}_{6}$ & 22 & 0 \\
\hline
\end{tabular}

${ }^{\mathrm{a}}$ All reactions were conducted at $50{ }^{\circ} \mathrm{C}$. ${ }^{\mathrm{b}}$ Benzaldehyde and the respective iodoarene 5 were the only reaction products detected by $\mathrm{GC}$ and $\mathrm{NMR}$. ${ }^{\mathrm{c}}$ The ratio of $\mathrm{PhCH}_{2} \mathrm{OH}$ to reagent 6 was 1:1. ${ }^{\mathrm{d}}$ Determined by ${ }^{1} \mathrm{H}$ NMR.

The oxidation of benzyl alcohol by reagents 7 in DMSO (Entries 2, 4, 6, 8, 10) under similar conditions afforded benzaldehyde with a very low conversion (0-7\%) (Table 1). The low reactivity towards alcohols in DMSO can be explained by the formation of a stable complex of iodoxyarene 7 with a molecule of DMSO, which leads to a lower electrophilicity of the iodine reagent. $^{11}$

Sulfonate esters 8 were found to be completely nonreactive in the oxidation of alcohols. This is similar to the reactivity of IBX-esters 3 which can oxidize alcohols only in the presence of trifluoroacetic acid. ${ }^{4 b}$ However, the esters 8 were found useful toward oxidation of other organic functional groups, such as sulfides and secondary amines (Scheme 4). In particular, the oxidation of a secondary amine with reagent 8 a proceeds at room temperature in dichloromethane with the formation of the respective imine $\mathbf{9}$ in good yield. Likewise, the reaction of organic sulfides with 
reagent $\mathbf{8 a}$ in refluxing acetonitrile leads to the formation of sulfoxides $\mathbf{1 0}$ without overoxidation to sulfones.

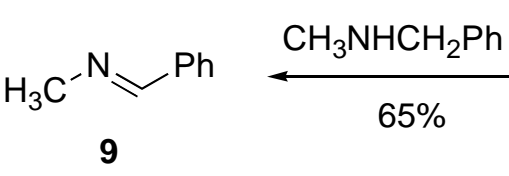

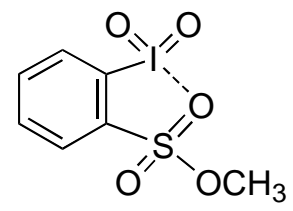

$8 a$

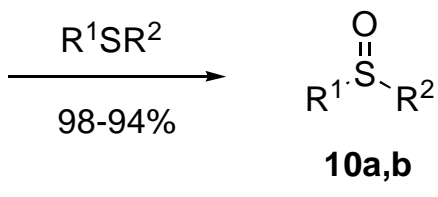

10a: $R^{1}=P h ; R^{2}=P h$

10b: $\mathrm{R}^{1}=\mathrm{CH}_{2} \mathrm{Ph} ; \mathrm{R}^{2}=\mathrm{Ph}$

\section{Scheme 4}

In conclusion, we have reported the preparation of new pseudobenziodoxole-based pentavalent iodine compounds, amides and esters of 2-iodoxybenzenesulfonic acid. These compounds are potentially useful reagents for mild oxidation of alcohols, sulfides and secondary amines.

\section{Experimental Section}

General Procedures. All melting points were determined in an open capillary tube with a Meltemp II ${ }^{\circledR}$ melting point apparatus and are uncorrected. Infrared spectra were recorded neat, as a $\mathrm{CCl}_{4}$ mull, or as a $\mathrm{KBr}$ pellet on a Perkin-Elmer 1600 series FT-IR spectrophotometer. NMR

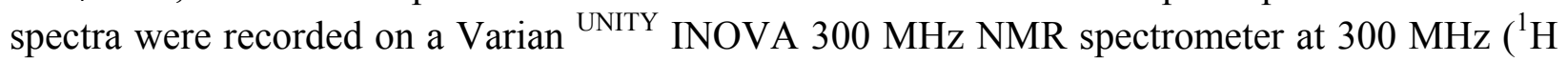
$\mathrm{NMR}$ ), and $75 \mathrm{MHz}\left({ }^{13} \mathrm{C} \mathrm{NMR}\right)$. Chemical shifts are reported in parts per million (ppm). ${ }^{1} \mathrm{H}$ chemical shifts are referenced relative to the residual nondeuteriated solvent of chloroform at $\delta$ 7.24. The ${ }^{13} \mathrm{C}$ chemical shifts are referenced relative to $\mathrm{CDCl}_{3}$ at $\delta$ 77.0. Mass-spectra were obtained with a Bruker Biotof II instrument. Microanalyses were carried out by Atlantic Microlab, Inc., Norcross, Georgia. All commercial reagents were ACS reagent grade and used without further purification. Methylene chloride was distilled from $\mathrm{CaH}_{2}$ immediately prior to use. All other reagents and solvents were of commercial quality from freshly opened containers. 2-Iodobenzenesulfonyl chloride was prepared by a known method. ${ }^{8}$ Dimethyldioxirane was prepared from commercial acetone and OXONE (Aldrich) by a known method. ${ }^{12}$ Reaction flasks were oven-dried at $200{ }^{\circ} \mathrm{C}$, flame-dried and flushed with dry nitrogen prior to use.

\section{General procedures for preparation of amides of 2-iodobenzenesulfonic acid}

To a stirred, ice-bath cooled mixture of L-amino acid methyl ester hydrochloride $(4.0 \mathrm{mmol}) \mathrm{in}$ $\mathrm{CH}_{2} \mathrm{Cl}_{2}(40 \mathrm{~mL})$, triethylamine $(8.0 \mathrm{mmol}, 1.11 \mathrm{ml})$ and 2-iodobenzenesulfonyl chloride $(1.51 \mathrm{~g}$, $5.0 \mathrm{mmol}$ ) were slowly added. After two hours of additional stirring, water $(40 \mathrm{~mL})$ was added and organic layer was separated. The organic layer was washed with $10 \% \mathrm{HCl}(1 \times 20 \mathrm{~m} 1)$. The 
solution was dried with $\mathrm{MgSO}_{4}$ and the solvent evaporated to give a yellow solid. Recrystallization from ethyl acetate/hexane (in case of $\mathbf{5 b}$ and $\mathbf{5 e}$ ) or column chromatography (in case of 5a, 5c and 5d, ethyl acetate/hexane 1:2 as eluent) and drying in vacuum resulted in the compounds 5.

Preparation of esters of 2-iodobenzenesulfonic acid. Esters of 2-iodobenzenesulfonic acid 6 were prepared by a known method without any modifications. ${ }^{9}$

\section{General procedure for oxidation of amides of 2-iodobenzenesulfonic acid}

Freshly prepared $0.1 \mathrm{M}$ solution of dimethyldioxirane in acetone $(30 \mathrm{~mL}, 3 \mathrm{mmol})$ was added to a stirred mixture of the appropriate amino acid derivative $5(1 \mathrm{mmol})$ in $5 \mathrm{~mL}$ of dry $\mathrm{CH}_{2} \mathrm{Cl}_{2}$ at $0{ }^{\circ} \mathrm{C}$. The color of the solution immediately changed from colorless to light yellow. The reaction mixture was stirred at room temperature for 8 hours and the resulting white microcrystalline precipitate was separated by filtration; then hexane was added to the filtered solution and the additional precipitate was filtered. Both precipitates were collected, washed with ether and dried in vacuum to afford analytically pure 7.

\section{General procedure for oxidation of esters of 2 -iodobenzenesulfonic acid}

Freshly prepared dimethyldioxirane was extracted with methylene chloride according to the known procedure. ${ }^{13}$ The solution of dimethyldioxirane in methylene chloride $(13 \mathrm{~mL}, 0.36 \mathrm{M})$ was added to the stirred mixture of ester $6(1 \mathrm{mmol})$ in $5 \mathrm{~mL}$ of methylene chloride at $0{ }^{\circ} \mathrm{C}$. The reaction mixture was stirred at room temperature for additional 8 hours, then the resulting white precipitate was collected by filtration, washed with ether and methylene chloride, and dried in vacuum to afford analytically pure sample of $\mathbf{8}$.

\section{General procedure for oxidation of alcohols}

(Method A) To the suspension of reagent $7(20 \mathrm{mg})$ in $2 \mathrm{~mL}$ of d-chloroform in an NMR tube, the equivalent amount of benzyl alcohol was added. The reaction mixture was heated up to 22 hours at $50{ }^{\circ} \mathrm{C}$. NMR spectra were recorded every 3 hours. The conversion of the benzyl alcohol was calculated from the relative integral intensity of the peaks at $10.06 \mathrm{ppm}$ (benzaldehyde) and $4.70 \mathrm{ppm}$ (benzyl alcohol). (Method B) To the solution of reagent 7 (20 mg) in $2 \mathrm{~mL}$ of DMSO$\mathrm{d}_{6}$ in NMR tube, the equivalent amount of benzyl alcohol was added. The reaction mixture was heated up to 14 hours at $50{ }^{\circ} \mathrm{C}$. NMR spectra were recorded every 3 hours. The conversion of the benzyl alcohol was calculated from the relative integral intensity of peaks at $10.06 \mathrm{ppm}$ (benzaldehyde) and $4.70 \mathrm{ppm}$ (benzyl alcohol).

\section{General procedure for oxidation of sulfides}

To a vigorously stirred suspension of ester $8 \mathbf{a}(0.15 \mathrm{mmol}, 50 \mathrm{mg})$ in $5 \mathrm{~mL}$ of acetonitrile, the appropriate sulfide was added $(0.25 \mathrm{mmol})$. The reaction mixture was stirred under reflux for approximately $1 \mathrm{hr}$, until the TLC showed consumption of the starting sulfide. Then the reaction 
mixture was concentrated on a rotary evaporator and separated by column chromatography (ethyl acetate/hexanes 1:2) to yield the final product.

\section{Typical procedure for oxidation of amines}

To a vigorously stirred suspension of ester $8 \mathbf{a}(0.15 \mathrm{mmol}, 50 \mathrm{mg})$ in $5 \mathrm{~mL}$ of methylene chloride, methyl benzyl amine was added $(0.3 \mathrm{mmol})$. The reaction mixture was stirred until the mixture became clear, and TLC showed consumption of the starting amine. Then the reaction mixture was concentrated on a rotary evaporator and separated by column chromatography (ethyl acetate/hexanes $1: 2)$ to yield the final product 9 (65\% yield), which was identical to the authentic commercial sample (from Aldrich) according to GC and NMR.

2-(2-Iodobenzenesulfonylamino)-propionic acid methyl ester (5a). Reaction of L-alanine methyl ester with 2-iodobenzenesulfonyl chloride according to general procedure afforded $1.05 \mathrm{~g} \mathrm{(71 \% )}$ of product 5a, isolated as a colorless oil. IR (KBr): 3294, 2952, 1736, 1341, $1169 \mathrm{~cm}^{-1} ;{ }^{1} \mathrm{H}$ NMR $\left(\mathrm{CDCl}_{3}\right): \delta 8.12\left(\mathrm{dd}, \mathrm{J}_{1}=7.8 \mathrm{~Hz}, \mathrm{~J}_{2}=1.7 \mathrm{~Hz}, 1 \mathrm{H}\right), 8.08\left(\mathrm{dd}, \mathrm{J}_{1}=7.8 \mathrm{~Hz}, \mathrm{~J}_{2}\right.$ $=1.2 \mathrm{~Hz}, 1 \mathrm{H}), 7.49\left(\mathrm{td}, \mathrm{J}_{1}=7.7 \mathrm{~Hz}, \mathrm{~J}_{2}=1.2 \mathrm{~Hz}, 1 \mathrm{H}\right), 7.21\left(\mathrm{td}, \mathrm{J}_{1}=7.6 \mathrm{~Hz}, \mathrm{~J}_{2}=1.7 \mathrm{~Hz}, 1 \mathrm{H}\right), 5.92$ $(\mathrm{d}, \mathrm{J}=7.8 \mathrm{~Hz}, 1 \mathrm{H}), 4.01(\mathrm{~m}, 1 \mathrm{H}), 3.56(\mathrm{~s}, 3 \mathrm{H}), 1.41(\mathrm{~d}, \mathrm{~J}=7.1 \mathrm{~Hz}, 3 \mathrm{H}) ;{ }^{13} \mathrm{C} \mathrm{NMR}\left(\mathrm{CDCl}_{3}\right): \delta$ 171.9, 142.3, 142.1, 133.5, 130.8, 128.4, 92.7, 52.6, 51.8, 19.6. Anal. Calcd. for $\mathrm{C}_{10} \mathrm{H}_{12} \mathrm{INO}_{4} \mathrm{~S}$ : C, 32.53; H, 3.28; N, 3.79; I, 34.37; S, 8.69. Found: C, 32.47; H, 3.30; N, 3.80; I, 34.20; S, 8.49. 2-(2-Iodobenzenesulfonylamino)-3-phenyl-propionic acid methyl ester (5b). Reaction of Lphenylalanine methyl ester with 2-iodobenzenesulfonyl chloride according to general procedure afforded $0.76 \mathrm{~g}(43 \%)$ of product $5 \mathbf{b}$, isolated as a colorless oil. IR (KBr): 3087, 2938, 1737 , 1344, $1161 \mathrm{~cm}^{-1} ;{ }^{1} \mathrm{H}$ NMR $\left(\mathrm{CDCl}_{3}\right): \delta 8.05\left(\mathrm{dd}, \mathrm{J}_{1}=7.8 \mathrm{~Hz}, \mathrm{~J}_{2}=1.7 \mathrm{~Hz}, 1 \mathrm{H}\right), 8.01\left(\mathrm{dd}, \mathrm{J}_{1}=\right.$ $\left.7.9 \mathrm{~Hz}, \mathrm{~J}_{2}=1.2 \mathrm{~Hz}, 1 \mathrm{H}\right), 7.45\left(\mathrm{td}, \mathrm{J}_{1}=7.7 \mathrm{~Hz}, \mathrm{~J}_{2}=1.2 \mathrm{~Hz}, 1 \mathrm{H}\right), 7.1(\mathrm{~m}, 6 \mathrm{H}), 5.74(\mathrm{~d}, \mathrm{~J}=8.6 \mathrm{~Hz}$, $1 \mathrm{H}), 4.25(\mathrm{~m}, 1 \mathrm{H}), 3.50(\mathrm{~s}, 3 \mathrm{H}), 3.06(\mathrm{~d}, \mathrm{~J}=6.1 \mathrm{~Hz}, 2 \mathrm{H}) ;{ }^{13} \mathrm{C} \mathrm{NMR}\left(\mathrm{CDCl}_{3}\right): \delta 170.7,142.3$, $142.0,134.8,133.3,130.6,129.4,128.6,128.3,127.4,92.7,57.1,52.4,39.3$.

2-(2-Iodobenzenesulfonylamino)-3-methyl-butyric acid methyl ester (5c). Reaction of Lvaline methyl ester with 2-iodobenzenesulfonyl chloride according to general procedure afforded $0.79 \mathrm{~g}(49 \%)$ of product 5c, isolated as a colorless oil. IR (KBr): 3351, 2963, 1741, 1341, $1161 \mathrm{~cm}^{-1} ;{ }^{1} \mathrm{H}$ NMR $\left(\mathrm{CDCl}_{3}\right): \delta 8.11\left(\mathrm{dd}, \mathrm{J}_{1}=8.1 \mathrm{~Hz}, \mathrm{~J}_{2}=1.7 \mathrm{~Hz}, 1 \mathrm{H}\right), 8.09\left(\mathrm{dd}, \mathrm{J}_{1}=7.8 \mathrm{~Hz}, \mathrm{~J}_{2}\right.$ $=1.2 \mathrm{~Hz}, 1 \mathrm{H}), 7.51\left(\mathrm{td}, \mathrm{J}_{1}=7.7 \mathrm{~Hz}, \mathrm{~J}_{2}=1.2 \mathrm{~Hz}, 1 \mathrm{H}\right), 7.23\left(\mathrm{td}, \mathrm{J}_{1}=7.6 \mathrm{~Hz}, \mathrm{~J}_{2}=1.4 \mathrm{~Hz}, 1 \mathrm{H}\right), 5.78$ $(\mathrm{d}, \mathrm{J}=9.8 \mathrm{~Hz}, 1 \mathrm{H}), 3.79(\mathrm{~m}, 1 \mathrm{H}), 3.48(\mathrm{~s}, 3 \mathrm{H}), 2.09(\mathrm{~m}, 1 \mathrm{H}), 0.96(\mathrm{~d}, \mathrm{~J}=5.1 \mathrm{~Hz}, 3 \mathrm{H}), 0.94(\mathrm{~d}, \mathrm{~J}$ $=5.3 \mathrm{~Hz}, 3 \mathrm{H}) ;{ }^{13} \mathrm{C} \mathrm{NMR}\left(\mathrm{CDCl}_{3}\right): \delta 171.0,142.2,142.0,133.4,130.7,128.4,92.8,61.6,52.2$, 31.6, 18.9, 17.7. Anal. Calcd. for $\mathrm{C}_{12} \mathrm{H}_{16} \mathrm{INO}_{4} \mathrm{~S}$ : C, 36.28; H, 4.06; N, 3.53; I, 31.95; S, 8.07. Found: C, 36.13; H, 4.02; N, 3.40; I, 31.82; S, 8.03.

2-(2-Iodobenzenesulfonylamino)-4-methyl-pentanoic acid methyl ester (5d). Reaction of Lleucine methyl ester with 2-iodobenzenesulfonyl chloride according to general procedure afforded $0.96 \mathrm{~g}(58 \%)$ of product 5d, isolated as a colorless oil. IR (KBr): 3299, 2963, 1739, 1341, $1166 \mathrm{~cm}^{-1} ;{ }^{1} \mathrm{H}$ NMR $\left(\mathrm{CDCl}_{3}\right): \delta 8.11\left(\mathrm{dd}, \mathrm{J}_{1}=8.1 \mathrm{~Hz}, \mathrm{~J}_{2}=1.7 \mathrm{~Hz}, 1 \mathrm{H}\right), 8.09\left(\mathrm{dd}, \mathrm{J}_{1}=7.8\right.$ $\left.\mathrm{Hz}, \mathrm{J}_{2}=1.2 \mathrm{~Hz}, 1 \mathrm{H}\right), 7.49\left(\mathrm{td}, \mathrm{J}_{1}=7.7 \mathrm{~Hz}, \mathrm{~J}_{2}=1.2 \mathrm{~Hz}, 1 \mathrm{H}\right), 7.20\left(\mathrm{td}, \mathrm{J}_{1}=7.6 \mathrm{~Hz}, \mathrm{~J}_{2}=1.4 \mathrm{~Hz}\right.$, $1 \mathrm{H}), 5.73(\mathrm{~d}, \mathrm{~J}=9.6 \mathrm{~Hz}, 1 \mathrm{H}), 3.98(\mathrm{~m}, 1 \mathrm{H}), 3.43(\mathrm{~s}, 3 \mathrm{H}), 1.78(\mathrm{~m}, 1 \mathrm{H}), 1.56(\mathrm{~m}, 2 \mathrm{H}), 0.90(\mathrm{~d}, \mathrm{~J}=$ 
$6.6 \mathrm{~Hz}, 3 \mathrm{H}), 0.85(\mathrm{~d}, \mathrm{~J}=6.3 \mathrm{~Hz}, 3 \mathrm{H}) ;{ }^{13} \mathrm{C} \mathrm{NMR}\left(\mathrm{CDCl}_{3}\right): \delta 171.9,142.2,141.9,133.4,130.8$, 128.4, 92.9, 54.8, 52.2, 42.0, 24.3, 22.6, 21.4. Anal. Calcd. for $\mathrm{C}_{13} \mathrm{H}_{18} \mathrm{INO}_{4} \mathrm{~S}: \mathrm{C}, 37.97$; H, 4.41; N, 3.41; I, 30.86; S, 7.80. Found: C, 37.88; H, 4.43; N, 3.43; I, 31.15; S, 7.83.

2-Iodo- $N$-(1-phenyl-ethyl)-benzenesulfonamide (5e). Reaction of R-(+)- $\alpha$-methylbenzylamine (0.484 g, $4 \mathrm{mmol})$ with 2-iodobenzenesulfonyl chloride afforded $0.74 \mathrm{~g}$ (48\%) of compound 5e as a white solid. MP 130-131 ${ }^{\circ} \mathrm{C}$ (with decomposition). IR (KBr): 3299, 3020, 3937, 13229, $1163 \mathrm{~cm}^{-1} ;{ }^{1} \mathrm{H}$ NMR $\left(\mathrm{CDCl}_{3}\right): \delta 7.97\left(\mathrm{dd}, \mathrm{J}_{1}=8.1 \mathrm{~Hz}, \mathrm{~J}_{2}=1.7 \mathrm{~Hz}, 1 \mathrm{H}\right), 7.91\left(\mathrm{dd}, \mathrm{J}_{1}=7.8 \mathrm{~Hz}, \mathrm{~J}_{2}\right.$ $=1.2 \mathrm{~Hz}, 1 \mathrm{H}), 7.35\left(\mathrm{td}, \mathrm{J}_{1}=7.7 \mathrm{~Hz}, \mathrm{~J}_{2}=1.2 \mathrm{~Hz}, 1 \mathrm{H}\right), 7.10(\mathrm{~m}, 6 \mathrm{H}), 5.19(\mathrm{~d}, 1 \mathrm{H}, \mathrm{J}=7.1 \mathrm{~Hz}, 1 \mathrm{H})$, $4.44(\mathrm{~m}, 1 \mathrm{H}), 1.47(\mathrm{~d}, \mathrm{~J}=6.8 \mathrm{~Hz}, 3 \mathrm{H}) ;{ }^{13} \mathrm{C} \mathrm{NMR}\left(\mathrm{CDCl}_{3}\right): \delta 138.0,137.4,136.4,128.5,126.5$, 124.0, 123.8, 123.2, 121.7, 88.1, 49.8, 18.5. Anal. Calcd. for $\mathrm{C}_{14} \mathrm{H}_{14} \mathrm{INO}_{2} \mathrm{~S}: \mathrm{C}, 43.42 ; \mathrm{H}, 3.64 ; \mathrm{N}$, 3.62; I, 32.77; S, 8.28. Found: C, 43.71; H, 3.71; N, 3.81; I, 32.48; S, 8.29.

Methyl ester of 2-iodobenzenesulfonic acid (6a). Reaction of 2-iodobenzenesulfonyl chloride ( $5 \mathrm{mmol}$ ) with methanol according to the general procedure afforded $1.01 \mathrm{~g}(68 \%)$ of product $6 \mathbf{6 a}$, isolated as white crystals, mp 68-69 ${ }^{\circ} \mathrm{C}$. IR ( NaCl): 3086, 1565, 1352, 1181, 981, 800, $765 \mathrm{~cm}^{-1}$; ${ }^{1} \mathrm{H}$ NMR $\left(\mathrm{CDCl}_{3}\right): \delta 8.13(\mathrm{~m}, 2 \mathrm{H}), 7.54\left(\mathrm{td}, \mathrm{J}_{1}=7.7 \mathrm{~Hz}, \mathrm{~J}_{2}=1.2 \mathrm{~Hz}, 1 \mathrm{H}\right),\left(\mathrm{dd}, \mathrm{J}_{1}=7.8 \mathrm{~Hz}, \mathrm{~J}_{2}=\right.$ $1.7 \mathrm{~Hz}, 1 \mathrm{H}), 3.82$ (s, 3H). ${ }^{13} \mathrm{C} \mathrm{NMR}\left(\mathrm{CDCl}_{3}\right): \delta 143.0,138.6,134.5,132.0,128.5,92.4,56.6$. Anal. Calcd for $\mathrm{C}_{7} \mathrm{H}_{7} \mathrm{IO}_{3} \mathrm{~S}: \mathrm{C}, 28.20 ; \mathrm{H}, 2.37$; S, 10.76. Found: C, 28.25; H, 2.38; S, 10.79.

Ethyl ester of 2-iodobenzenesulfonic acid (6b). Reaction of 2-iodobenzenesulfonyl chloride $(5 \mathrm{mmol})$ with ethanol according to the general procedure afforded $1.01 \mathrm{~g}(65 \%)$ of product $\mathbf{6 b}$, isolated as white crystals, mp 33-34 ${ }^{\circ} \mathrm{C}$. IR ( NaCl): 2987, 1569, 1354, 1185, 999, 803, $759 \mathrm{~cm}^{-1}$; ${ }^{1} \mathrm{H}$ NMR (DMSO-d $\left.)_{6}\right): \delta .13(\mathrm{~d}, \mathrm{~J}=7.8, \mathrm{~Hz}, 2 \mathrm{H}), 7.53(\mathrm{t}, \mathrm{J}=7.7 \mathrm{~Hz}, 1 \mathrm{H}), 7.28\left(\mathrm{td}, \mathrm{J}_{1}=7.7 \mathrm{~Hz}\right.$, $\left.\mathrm{J}_{2}=1.5 \mathrm{~Hz}, 1 \mathrm{H}\right), 4.18(\mathrm{q}, \mathrm{J}=7.1 \mathrm{~Hz}, 2 \mathrm{H}), 1.39(\mathrm{t}, \mathrm{J}=7.1 \mathrm{~Hz}, 3 \mathrm{H}) .{ }^{13} \mathrm{C} \mathrm{NMR}\left(\mathrm{CDCl}_{3}\right): \delta 143.0$, 139.5, 134.4, 131.8, 128.4, 92.4, 67.7, 14.8. Anal. Calcd for $\mathrm{C}_{8} \mathrm{H}_{9} \mathrm{IO}_{3} \mathrm{~S}: \mathrm{C}, 30.78 ; \mathrm{H}, 2.91$; , 10.27. Found: C, 31.00; H, 2.90; S, 10.16.

2-(2-Iodoxybenzenesulfonylamino)-propionic acid methyl ester (7a). Oxidation of 2-(2-iodobenzenesulfonylamino)-propionic acid methyl ester $\mathbf{5 a}$ according to general procedure afforded $383 \mathrm{mg}(96 \%)$ of product $7 \mathbf{a}$, isolated as white crystals, mp. $150-151^{\circ} \mathrm{C}$. IR (KBr): 3012,2858 , 1718, 1337, 1144, 800, $751 \mathrm{~cm}^{-1} ;{ }^{1} \mathrm{H}$ NMR $\left(\mathrm{DMSO}_{-}\right): \delta 8.68(\mathrm{~d}, \mathrm{~J}=8.4 \mathrm{~Hz}, 1 \mathrm{H}), 8.27\left(\mathrm{dd}, \mathrm{J}_{1}=\right.$ $\left.7.8 \mathrm{~Hz}, \mathrm{~J}_{2}=1.2 \mathrm{~Hz}, 1 \mathrm{H}\right), 7.99\left(\mathrm{td}, \mathrm{J}_{1}=7.5 \mathrm{~Hz}, \mathrm{~J}_{2}=1.5 \mathrm{~Hz}, 1 \mathrm{H}\right), 7.91\left(\mathrm{dd}, \mathrm{J}_{1}=7.8 \mathrm{~Hz}, \mathrm{~J}_{2}=\right.$ $1.5 \mathrm{~Hz}, 1 \mathrm{H}), 7.83\left(\mathrm{td}, \mathrm{J}_{1}=7.4 \mathrm{~Hz}, \mathrm{~J}_{2}=1.5 \mathrm{~Hz}, 1 \mathrm{H}\right), 4.40(\mathrm{~m}, 1 \mathrm{H}), 3.50(\mathrm{~s}, 3 \mathrm{H}), 1.06(\mathrm{~d}, \mathrm{~J}=$ 7.2 Hz, 3H); ${ }^{13} \mathrm{C}$ NMR (DMSO-d 6 ): $\delta 171.9,146.6,137.7,133.6,132.3,128.4,123.5,52.1,50.4$, 18.4. Anal. Calcd. for $\mathrm{C}_{10} \mathrm{H}_{12} \mathrm{INO}_{6} \mathrm{~S}: \mathrm{C}, 29.94 ; \mathrm{H}, 3.01 ; \mathrm{N}, 3.49 ; \mathrm{I}, 31.63 ; \mathrm{S}, 7.99$. Found: C, 30.09; H, 3.00; N, 3.52; I, 31.36; S, 7.92. ESI MS: m/z (\%) 423.93 (100), [M+Na] $]^{+}$

2-(2-Iodoxybenzenesulfonylamino)-3-phenyl-propionic acid methyl ester (7b). Oxidation of 2-(2-iodobenzenesulfonylamino)-3-phenyl-propionic acid methyl ester $\mathbf{5 b}$ according to general procedure afforded $327 \mathrm{mg}(68 \%)$ of product $\mathbf{7 b}$, isolated as white crystals, mp. $127-128{ }^{\circ} \mathrm{C}$. IR (KBr): 3067, 2992, 1735, 1322, 1154, 803, $770 \mathrm{~cm}^{-1}$; ${ }^{1} \mathrm{H}$ NMR (DMSO-d $)$ ): $\delta 8.76$ (d, J = 9.0 Hz, $1 \mathrm{H}), 8.21(\mathrm{~d}, \mathrm{~J}=7.6 \mathrm{~Hz}, 1 \mathrm{H}), 7.92\left(\mathrm{td}, \mathrm{J}_{1}=7.1 \mathrm{~Hz}, \mathrm{~J}_{2}=1.7 \mathrm{~Hz}, 1 \mathrm{H}\right), 7.62(\mathrm{~m}, 2 \mathrm{H}), 7.13(\mathrm{~m}, 5 \mathrm{H})$, $4.61(\mathrm{~m}, 1 \mathrm{H}), 3.43(\mathrm{~s}, 3 \mathrm{H}), 2.92(\mathrm{~m}, 1 \mathrm{H}), 2.69(\mathrm{~m}, 1 \mathrm{H}) ;{ }^{13} \mathrm{C}$ NMR (DMSO-d $): \delta 171.0,146.3$, $137.3,135.8,133.4,132.2,129.2,128.1,126.6,123.4,109.5,55.9,52.0,38.0$. Anal. Calcd. for 
$\mathrm{C}_{16} \mathrm{H}_{16} \mathrm{INO}_{6} \mathrm{~S}: \mathrm{C}, 40.26 ; \mathrm{H}, 3.38 ; \mathrm{N}, 2.93 ; \mathrm{I}, 26.59 ; \mathrm{S}, 6.72$. Found: C, 40.21; H, 3.00; N, 3.52; I, 31.36; S, 7.92. ESI MS: m/z (\%) $499.96(80),[\mathrm{M}+\mathrm{Na}]^{+}$.

2-(2-Iodoxybenzenesulfonylamino)-3-methyl-butyric acid methyl ester (7c). Oxidation of 2(2-iodobenzenesulfonylamino)-3-methyl-butyric acid methyl ester 5c according to general procedure afforded $360 \mathrm{mg}(84 \%)$ of product 7c, isolated as white crystals, mp. $158-159{ }^{\circ} \mathrm{C}$. IR (KBr): 2978, 1718, 1332, 1146, 803, $773 \mathrm{~cm}^{-1}$; ${ }^{1} \mathrm{H}$ NMR (DMSO-d 6 ): $\delta 8.49$ (d, J = 9.3 Hz, 1H), $8.25(\mathrm{~d}, \mathrm{~J}=7.8 \mathrm{~Hz}, 1 \mathrm{H}), 7.98(\mathrm{t}, \mathrm{J}=6.7 \mathrm{~Hz}, 1 \mathrm{H}), 7.88(\mathrm{~d}, \mathrm{~J}=6.6 \mathrm{~Hz}, 1 \mathrm{H}), 7.81(\mathrm{t}, \mathrm{J}=7.3 \mathrm{~Hz}$, $1 \mathrm{H}), 4.18(\mathrm{~m}, 1 \mathrm{H}), 3.43(\mathrm{~s}, 3 \mathrm{H}), 1.96(\mathrm{~m}, 1 \mathrm{H}), 0.74(\mathrm{~d}, \mathrm{~J}=5.9 \mathrm{~Hz}, 3 \mathrm{H}), 0.72(\mathrm{~d}, \mathrm{~J}=6.6 \mathrm{~Hz}, 3 \mathrm{H})$; ${ }^{13} \mathrm{C}$ NMR (DMSO-d $): \delta 170.8,150.8,137.3,133.4,131.9,128.1,123.5,60.0,51.6,30.3,18.5$, 18.2. Anal. Calcd. for $\mathrm{C}_{12} \mathrm{H}_{16} \mathrm{INO}_{6} \mathrm{~S}$ : C, 33.58; H, 3.76; N, 3.26; I, 29.57; S, 7.47. Found: C, 33.62; H, 3.78; N, 3.32; I, 29.29; S, 7.35. ESI MS: m/z (\%) $451.96(80),[\mathrm{M}+\mathrm{Na}]^{+}$.

2-(2-Iodoxybenzenesulfonylamino)-4-methyl-pentanoic acid methyl ester (7d). Oxidation of 2-(2-iodobenzenesulfonylamino)-4-methyl-pentanoic acid methyl ester 5d according to general procedure afforded $281 \mathrm{mg}(63 \%)$ of product $7 \mathbf{d}$, isolated as white crystals, mp. $154-155^{\circ} \mathrm{C}$. IR (KBr): 3017, 2958, 1747, 1334, 1146, 805, $768 \mathrm{~cm}^{-1}$; ${ }^{1} \mathrm{H}$ NMR (DMSO-d $)$ ): $\delta 8.64$ (d, J = 8.6 Hz, 1H), 8.25 (d, J = 7.8 Hz, 1H), $7.99(\mathrm{t}, \mathrm{J}=6.9 \mathrm{~Hz}, 1 \mathrm{H}) 87.86(\mathrm{~m}, 2 \mathrm{H}), 4.27(\mathrm{~m}, 1 \mathrm{H}), 3.42(\mathrm{~s}, 3 \mathrm{H})$, $1.45(\mathrm{~m}, 3 \mathrm{H}), 0.78(\mathrm{~d}, \mathrm{~J}=6.3 \mathrm{~Hz}, 3 \mathrm{H}), 0.61(\mathrm{~d}, \mathrm{~J}=6.6 \mathrm{~Hz}, 3 \mathrm{H}) ;{ }^{13} \mathrm{C}$ NMR $\left(\mathrm{DMSO}_{6}\right)$ ) $\delta 172.0$, $146.5,137.4,133.5,132.1,128.3,123.6,53.2,51.9,40.9,23.9,22.8,20.9$. Anal. Calcd. for $\mathrm{C}_{13} \mathrm{H}_{18} \mathrm{INO}_{6} \mathrm{~S}: \mathrm{C}, 35.23 ; \mathrm{H}, 4.09 ; \mathrm{N}, 3.16$; I, 28.63; S, 7.23. Found: C, 34.97; H, 4.08; N, 3.17; I, 28.87; S, 7.20. ESI MS: m/z (\%) 465.98 (100), [M+Na $]^{+}$.

2-Iodoxy- $N$-(1-phenyl-ethyl)-benzenesulfonamide (7e). Oxidation of 2-iodo- $N$-(1-phenylethyl)-benzenesulfonamide 5e according to general procedure afforded $280 \mathrm{mg}(67 \%)$ of product 7e, isolated as white crystals, mp. $140-141{ }^{\circ} \mathrm{C}$. IR (KBr): 3062, 2982, 1327, 1156, $785 \mathrm{~cm}^{-1} ;{ }^{1} \mathrm{H}$ NMR (DMSO-d $\left.)_{6}\right): \delta 8.52(\mathrm{~d}, \mathrm{~J}=8.3 \mathrm{~Hz}, 1 \mathrm{H}), 8.25\left(\mathrm{dd}, \mathrm{J}_{1}=7.8 \mathrm{~Hz}, \mathrm{~J}_{2}=1.0 \mathrm{~Hz}, 1 \mathrm{H}\right), 7.91\left(\mathrm{td}, \mathrm{J}_{1}\right.$ $\left.=7.3 \mathrm{~Hz}, \mathrm{~J}_{2}=1.9 \mathrm{~Hz}, 1 \mathrm{H}\right), 7.68(\mathrm{~m}, 2 \mathrm{H}), 7.18(\mathrm{~m}, 5 \mathrm{H}), 4.66(\mathrm{~m}, 1 \mathrm{H}), 1.15(\mathrm{~d}, \mathrm{~J}=6.7 \mathrm{~Hz}, 3 \mathrm{H})$; ${ }^{13} \mathrm{C}$ NMR (DMSO-d 6 ): $\delta$ 146.3, 142.9, 137.8, 133.3, 132.1, 128.2, 128.1, 126.9, 126.1, 123.6, 51.8, 23.1. Anal. Calcd. for $\mathrm{C}_{14} \mathrm{H}_{14} \mathrm{INO}_{6} \mathrm{~S}: \mathrm{C}, 40.11 ; \mathrm{H}, 3.37$; N, 3.34; I, 30.27; S, 7.65. Found: C, 40.14; H, 3.32; N, 3.51; I, 30.12; S, 7.70. ESI MS: m/z (\%) 441.95 (100), [M+Na] $]^{+}$

Methyl ester of 2-iodoxybenzenesulfonic acid (8a). Oxidation of methyl ester of 2iodobenzenesulfonic acid 6a $(0.29 \mathrm{~g}, 1 \mathrm{mmol})$ according to the general procedure afforded $0.29 \mathrm{~g}$ $(89 \%)$ of product 8a, isolated as white crystals, mp $199-201{ }^{\circ} \mathrm{C}$ (with decomposition). IR $(\mathrm{NaCl})$ : 3074, 2360, 1348, 1179, 967, 804, 779, $750 \mathrm{~cm}^{-1} ;{ }^{1} \mathrm{H} \mathrm{NMR}\left(\mathrm{CDCl}_{3}+1 \% \mathrm{CF}_{3} \mathrm{COOH}\right): \delta 8.48(\mathrm{~d}$, $\mathrm{J}=7.6 \mathrm{~Hz}, 1 \mathrm{H}), 8.12(\mathrm{t}, \mathrm{J}=7.3 \mathrm{~Hz}, 1 \mathrm{H}), 8.02(\mathrm{~d}, \mathrm{~J}=7.3 \mathrm{~Hz}, 1 \mathrm{H}), 7.92(\mathrm{t}, \mathrm{J}=7.3 \mathrm{~Hz}, 1 \mathrm{H}), 3.78$ (s, 3H). ${ }^{13} \mathrm{C} \mathrm{NMR}\left(\mathrm{CDCl}_{3}+1 \% \mathrm{CF}_{3} \mathrm{COOH}\right): \delta 146.0,136.7,134.4,131.5,130.0,125.1,59.0$. Anal. Calcd for $\mathrm{C}_{7} \mathrm{H}_{7} \mathrm{IO}_{5} \mathrm{~S}: \mathrm{C}, 25.47$; H, 2.14; I, 38.44; S, 9.71. Found: C, 25.40; H, 2.17; I, 38.16; S, 9.79. ESI HRMS: m/z (\%) 336.9003 (100), [M+Na] $]^{+}$

Ethyl ester of 2-iodoxybenzenesulfonic acid (8b). Oxidation of ethyl ester of 2iodobenzenesulfonic acid $\mathbf{6 b}(0.31 \mathrm{~g}, 1 \mathrm{mmol})$ according to the general procedure afforded $0.29 \mathrm{~g}(84 \%)$ of product $\mathbf{8 b}$, isolated as white crystals, mp $79-80{ }^{\circ} \mathrm{C}$ (with decomposition). IR (KBr): 3073, 1426, 1348, 1174, 990, $772 \mathrm{~cm} ;{ }^{1} \mathrm{H}$ NMR $\left(\mathrm{CDCl}_{3}+1 \% \mathrm{CF}_{3} \mathrm{COOH}\right): \delta 8.53(\mathrm{~d}, \mathrm{~J}=$ 
$8.1 \mathrm{~Hz}, 1 \mathrm{H}), 8.16\left(\mathrm{td}, \mathrm{J}_{1}=7.8 \mathrm{~Hz}, \mathrm{~J}_{2}=1.5 \mathrm{~Hz}, 1 \mathrm{H}\right), 8.08\left(\mathrm{dd}, \mathrm{J}_{1}=7.8 \mathrm{~Hz}, \mathrm{~J}_{2}=1.5 \mathrm{~Hz}, 1 \mathrm{H}\right), 7.97$ $\left(\mathrm{dd}, \mathrm{J}_{1}=7.6 \mathrm{~Hz}, \mathrm{~J}_{2}=1.0 \mathrm{~Hz}, 1 \mathrm{H}\right), 4.30(\mathrm{q}, \mathrm{J}=7.1 \mathrm{~Hz}, 2 \mathrm{H}), 1.33(\mathrm{t}, \mathrm{J}=7.1 \mathrm{~Hz}, 3 \mathrm{H}) .{ }^{13} \mathrm{C} \mathrm{NMR}$ $\left(\mathrm{CDCl}_{3}+1 \% \mathrm{CF}_{3} \mathrm{COOH}\right): \delta 146.1,136.4,133.9,132.3,129.6,124.9,70.9,14.5$. Anal. Calcd for $\mathrm{C}_{8} \mathrm{H}_{9} \mathrm{IO}_{5} \mathrm{~S}: \mathrm{H}, 2.64 ; \mathrm{I}, 36.88 ; \mathrm{S}, 9.32$. Found: H, 2.69; I, 37.06; S, 9.37.

\section{Oxidation of sulfides}

Diphenyl sulfoxide. Oxidation of diphenyl sulfide according to the general procedure afforded $50 \mathrm{mg}(98 \%)$ of product 10a, isolated as white crystals, mp $69-71{ }^{\circ} \mathrm{C} .{ }^{14}{ }^{1} \mathrm{H} \mathrm{NMR}\left(\mathrm{CDCl}_{3}\right): \delta 7.65$ (m, 4H), $7.44(\mathrm{~m}, 6 \mathrm{H}) ;{ }^{13} \mathrm{C} \mathrm{NMR}\left(\mathrm{CDCl}_{3}\right): \delta 145.6,131.0,129.3,124.7$.

Phenyl benzyl sulfoxide. Oxidation of phenyl benzyl sulfide according to the general procedure afforded $51 \mathrm{mg}(94 \%)$ of product 10b, isolated as white crystals, mp $124-126{ }^{\circ} \mathrm{C}^{15}{ }^{1} \mathrm{H}$ NMR $\left(\mathrm{CDCl}_{3}\right): \delta 7.45-7.34(\mathrm{~m}, 5 \mathrm{H}), 7.25(\mathrm{~m}, 3 \mathrm{H}), 6.97\left(\mathrm{dd}, \mathrm{J}_{1}=7.8 \mathrm{~Hz}, \mathrm{~J}_{2}=1.5 \mathrm{~Hz}, 2 \mathrm{H}\right), 4.04(\mathrm{~m}$, $2 \mathrm{H}) ;{ }^{13} \mathrm{C} \mathrm{NMR}\left(\mathrm{CDCl}_{3}\right): \delta 142.7,131.1,130.3,129.1,128.8,128.4,128.2,124.4,63.5$.

\section{Acknowledgements}

This work was supported by a research grant from the National Institutes of Health (R15 GM065148-01) and by NSF-MRI award CHE-0416157.

\section{References and Footnotes}

1. (a) Varvoglis, A. Hypervalent Iodine in Organic Synthesis; Academic Press: London, 1997.

(b) Hypervalent Iodine Chemistry; Wirth, T., Ed.; Topics in Current Chemistry, 2003; Vol. 224, Springer-Verlag, Berlin Heidelberg. (c) Morales-Rojas, H.; Moss, R. A. Chem. Rev. 2002, 102, 2497. (d) Zhdankin, V. V.; Stang, P. J. Chem. Rev. 2002, 102, 2523. (e) Zhdankin, V. V. Rev. Heteroatom Chem. 1997, 17, 133. (f) Wirth, T.; Hirt, U. H. Synthesis 1999, 1271. (g) Wirth, T. Angew. Chem., Int. Ed. 2001, 40, 2812.

2. Nicolaou, K. C.; Mathison, C. J. N.; Montagnon, T. J. Am. Chem. Soc. 2004, 126, 2004.

3. (a) Thottumkara, A. P.; Vinod, T. K. Tetrahedron Lett. 2002, 43, 569. (b) Zhdankin, V. V.; Smart, J. T.; Zhao, P.; Kiprof, P. Tetrahedron Lett. 2000, 41, 5299. (c) Ozanne, A.; Pouysegu, L.; Depernet, D.; Francois, B.; Quideau, S. Org. Lett. 2003, 5, 2903.

4. (a) Zhdankin, V. V.; Koposov, A. Y.; Netzel, B. C.; Yashin, N. V.; Rempel, B. P.; Ferguson, M. J.; Tykwinski, R. R. Angew. Chem., Int. Ed. 2003, 42, 2194. (b) Zhdankin, V. V.; Litvinov, D. N.; Koposov, A. Y.; Luu, T.; Ferguson, M. J.; McDonald, R.; Tykwinski, R. R. J. Chem. Soc., Chem. Commun. 2004, 106.

5. (a) Mülbaier, M.; Giannis, A. Angew. Chem., Int. Ed. 2001, 40, 4393. (b) Mulbaier, M.; Giannis, A. ARKIVOC 2003, 228. (c) Sorg, G.; Mengel, A.; Jung, G.; Rademann, J. Angew. Chem. Int. Ed. 2001, 40, 4395. (d) Reed, N. N.; Delgado, M.; Hereford, K.; Clapham, B.; 
Janda, K. D. Bioorg. Med. Chem.Lett. 2002, 12, 2047. (e) Lei, Z.; Denecker, C.; Jegasothy, S.; Sherrington, D. C.; Slater, N. K. H.; Sutherland, A. J. Tetrahedron Lett. 2003, 44, 1635.

6. Chung, W.-J.; Kim, D.-K.; Lee, Y.-S. Tetrahedron Lett. 2003, 44, 9251.

7. For a preliminary communication on the preparation of 2-iodoxybenzenesulfonamides see: Koposov, A. Y.; Litvinov, D. N.; Zhdankin, V. V. Tetrahedron Lett. 2004, 45, 2719.

8. Chau, M. M.; Kice, J. L. J. Org. Chem. 1977, 42, 3265.

9. Gilman, H.; Beaber, N. J. J. Am. Chem. Soc. 1924, 47, 518.

10. (a) Macikenas, D.; Skrzypczak-Jankun, E.; Protasiewicz, J. D. Angew. Chem., Int. Ed. 2000, 39, 2007. (b) Macikenas, D.; Skrzypczak-Jankun, E.; Protasiewicz, J. D. J. Am. Chem. Soc. 1999, 121, 7164. (c) Meprathu, B. V.; Protasiewicz, J. D. ARKIVOC 2003, 83. (d) Hirt, U. H.; Schuster, M. F. H.; French, A. N.; Wiest, O. G.; Wirth, T. Eur. J. Org. Chem. 2001, 1569. (e) Hirt, U. H.; Spingler, B.; Wirth, T. J. Org. Chem. 1998, 63, 7674. (f) Nikiforov, V. A.; Karavan, V. S.; Miltsov, S. A.; Selivanov, S. I.; Kolehmainen, E.; Wegelius, E.; Nissinen, M. ARKIVOC 2003, 191.

11. Nicolaou, K. C.; Montagnon, T.; Baran, P. S. Angew. Chem., Int. Ed. 2002, 41, 993.

12. Adam, W.; Bialas, J.; Hadjiarapoglou, L. Chem. Ber. 1991, 124, 3277.

13. Gilbert, M.; Ferrer, M.; Sanchez-Baeza, F.; Messeguer, A. Tetrahedron 1997, 53, 8643.

14. Aldrich Catalog, 2003.

15. Russell, G. A.; Pecoraro, J. M. J. Org. Chem. 1979, 44, 3990. 